\title{
ARTICLE
}

\section{Antagonistic activity of terrestrial Streptomyces sp. VITNK9 against Gram negative bacterial pathogens affecting the fish and shellfish in aquaculture}

Actividad antagonista de Streptomyces sp. VITNK9 contra patógenos bacterianos Gram negativos que afectan a los peces y mariscos en la acuicultura

\section{Mohammed Ishaque Nabila ${ }^{1}$ and Krishnan Kannabiran ${ }^{1, *}$}

${ }^{1}$ Department of Biomedical Sciences, School of Biosciences and Technology, Vellore Institute of Technology, Vellore632014, Tamil Nadu, India.*Corresponding author: kkb@vit.ac.in

Resumen.- Se realizaron un total de 72 aislamientos de actinomicetos morfológicamente diferentes a partir de muestras recolectadas en diferentes regiones de Vellore, Tamil Nadu, India y seleccionados por su actividad antibacteriana contra patógenos de peces y mariscos. Todos los aislamientos de actinomicetos fueron examinados para determinar la actividad antibacteriana por el método de rayas cruzadas contra los patógenos seleccionados de peces y mariscos incluyendo Aeromonas caviae, Aeromonas hydroplila, Edwardsiella tarda, Vibrio anguillarum, Vibrio harveyi. El tamizaje secundario de aislamientos antagonistas por el método de difusión de pozos conduce a la identificación de aislamiento potencial. Las condiciones de cultivo para el aislamiento potencial fue optimizado para un crecimiento y rendimiento máximo del extracto bruto de acetato de etilo (EA). El aislamiento potencial se caracterizó por la taxonomía molecular y filogenia identificándose la especie como Streptomyces y nombrado Streptomyces sp. VITNK9. La secuencia de nucleótidos 16S rDNA fue buscada a través de la base de datos GenBank y mostró $83 \%$ de similitud con Streptomyces vinaceusdrappus. El extracto EA preparado a partir de Streptomyces sp. VITNK9 mostró actividad antagonista moderada a la que se accede por la zona de formación de inhibición del crecimiento, Aeromonas caviae $(15,33 \mathrm{~mm})$, Aeromonas hydrophila $(17,66 \mathrm{~mm})$, Edwardsiella tarda $(18,33$ $\mathrm{mm})$, Vibrio anguillarum $(14,33 \mathrm{~mm})$ y Vibrio harveyi $(14,33 \mathrm{~mm})$. El valor de CIM del extracto de EA estaba comprendido entre 0,03 y $0,125 \mathrm{mg} \mathrm{mL}^{-1}$. El espectro de GC-MS del extracto de acetato de etilo reveló la presencia de dos compuestos principales, pirrolo [1,2-a] pirazina-1,4-diona (56,67\%) y hexahidro-3- (2-metilpropil) (27,91\%), respectivamente. Los resultados del estudio sugieren que Streptomyces sp. VITNK9 es una fuente potencial de metabolitos secundarios antagónicos contra patógenos de peces y mariscos.

Palabras clave: Streptomyces, patógenos de peces y mariscos, actividad antibacteriana, metabolitos secundarios, análisis filogenético

\begin{abstract}
A total of 72 morphologically different actinomycetes isolates were isolated from samples collected at different regions of Vellore, Tamil Nadu, India and screened for its antibacterial activity against fish and shellfish pathogens. All actinomycetes isolates were screened for antibacterial activity by cross streak method against the selected fish and shellfish bacterial pathogens including Aeromonas caviae, Aeromonas hydroplila, Edwardsiella tarda, Vibrio anguillarum and Vibrio harveyi. Secondary screening of antagonistic isolates by well diffusion method leads to the identification of potential isolate. Culture conditions for the potential isolate were optimized for maximal growth and yield of the ethyl acetate (EA) crude extract. The potential isolate was characterized by molecular taxonomy and phylogeny and identified as Streptomyces species and named as Streptomyces sp. VITNK9. The $16 \mathrm{~S}$ rDNA nucleotide sequence was searched through the GenBank database and showed $83 \%$ similarity to Streptomyces vinaceusdrappus. The EA extract prepared from Streptomyces sp. VITNK9 showed moderate antagonistic activity accessed by the formation of zone of growth inhibition against, Aeromonas caviae $(15.33 \mathrm{~mm})$, Aeromonas hydrophila $(17.66 \mathrm{~mm})$, Edwardsiella tarda $(18.33 \mathrm{~mm})$, Vibrio anguillarum $(14.33 \mathrm{~mm})$ and Vibrio harveyi $(14.33 \mathrm{~mm})$. The MIC value of EA extract was ranged between $0.03-0.125 \mathrm{mg} \mathrm{mL}^{-1}$. The GC-MS spectrum of the ethyl acetate extract revealed the presence of two major compounds, pyrrolo [1,2-A] pyrazine1,4-Dione (56.67\%) and Hexahydro-3-(2-Methylpropyl) (27.91\%), respectively. The results of the study suggest that Streptomyces sp. VITNK9 is a potential source for antagonistic secondary metabolites against fish and shellfish bacterial pathogens.
\end{abstract}

Key words: Streptomyces, fish and shellfish pathogens, antibacterial activity, secondary metabolites, phylogenetic analysis 


\section{INTRODUCTION}

Aquaculture appears to be one of the last frontiers by increasing its contributions to food security in the developing countries (Aly \& Albutti 2014). Intensification of aquaculture has led to the conditions favouring the development of various fish diseases. In particular, fish bacterial diseases are responsible for heavy mortality in both wild and cultured fishes. This, in turn, leads to heavy financial losses to the fish farmers. Aquaculture management and disease control have become one of the major problems as the fish bacterial pathogens have become resistant to the conventional drugs being used in the aquaculture industry. Bacterial fish diseases such as hemorrhagic septicemia, edwardsiellosis, bacterial kidney disease, bacterial gill disease, pop eye, vibriosis, fin and tail rot were reported by different workers from different parts of the world (Selvakumar et al. 2010, Sihag \& Sharma 2012). Vibriosis is a major disease caused by Vibrio sp. affecting all varieties of shrimps at all stages. The major species causing vibriosis in shrimp are Vibrio alginolyticus, $V$. harveyi, $V$. anguillarum and $V$. parahemolyticus (Goarant et al. 1999, Letchumanan et al. 2014, Wang et al. 2015, Santhakumari et al. 2016). Several strategies have been proposed in control of vibriosis. For example, vaccines have been developed, but generally, cannot be used as a universal disease control measure in aquaculture as they are too much time consuming and labour-intensive (You et al. 2005). So antibiotics and chemotherapeutics remain the method of choice for disease control in the aquaculture industry. Hence, there is an urgent need for the search of safe, effective and novel bioactive compounds from natural sources to deal with the fish bacterial pathogens and to control them in an eco-friendly manner (Thirumurugan \& Vijayakumar 2013). Unexploited habitats still remain as a promising source for the discovery of novel bioactive compounds.

Microorganisms are playing a great role in the expansion of drug development. Especially, soil-dwelling microorganisms remain as an excellent resource for the isolation and identification of therapeutically important products. Among them, actinomycetes are extensively distributed in the soil providing many important secondary metabolites of high medical importance, commercial value, and diverse biological applications. Actinomycetes are aerobic, filamentous, spore-forming Gram-positive bacteria with high $\mathrm{G}+\mathrm{C}$ (60-70\%) content in DNA. They are the prime sources of novel bioactive compounds like antibiotics, enzymes and other bioactive compounds (Roshan et al. 2013). Extensive screening of terrestrial actinomycetes has also yielded many important drug leads. Actinomycetes produce more than half of the bioactive compounds in the antibiotic literature database (Lazzarini et al. 2000). The Streptomyces genera of the actinomycetes group are the dominant and primary antibiotic-producing organisms exploited by the pharmaceutical industry.

Streptomyces species are capable of forming heat and desiccation-resistant spores and also most of them are non-pathogenic to plants and animals. Hence, the Streptomyces species isolated from terrestrial origin has been considered as potential biocontrol agents (You et al. 2005). Approximately 7,600 bioactive compounds have been reported from Streptomyces species (Berdy 2005). Actinomycetes have also shown interesting activities in water such as degradation of starch and casein and production of antimicrobial agents. With such types of bioactivities, actinomycetes would play an important role in dealing with the fish bacterial pathogens (Zheng et al. 2000). There are studies on the bioactivity of actinomycetes, in particular, Streptomyces species against human and fish pathogens (Patil et al. 2001). Actinomycetes remain as one of the major natural source for novel and therapeutically bioactive compounds. Among them, many have been developed into drugs for the treatment of wide range of diseases of humans, plants and animals (Vaid \& Sajeevan 2016). The objective of present investigation was the isolation, characterization and screening of actinomycetes isolated from the terrestrial regions of Vellore, Tamil Nadu, India, against fish and shellfish pathogens.

\section{Materials ANd Methods}

\section{SoIL SAMPLING}

In the present study, soil samples were collected from different locations of Vellore district $\left(12.9165^{\circ} \mathrm{N}\right.$, $\left.79.1325^{\circ} \mathrm{E}\right)$, Ambur $\left(12.9165^{\circ} \mathrm{N}, 79.1325^{\circ} \mathrm{E}\right)$, Madhanur $\left(11.2777^{\circ} \mathrm{N}, 76.9920^{\circ} \mathrm{E}\right)$, Gudiyatham $\left(12.9447^{\circ} \mathrm{N}\right.$, $\left.78.8709^{\circ} \mathrm{E}\right)$ and Katpadi $\left(12.9796^{\circ} \mathrm{N}, 79.1375^{\circ} \mathrm{E}\right)$, Tamil Nadu, India. The soil samples were collected at a depth of $5-10 \mathrm{~cm}$ under aseptic conditions in a sterile polyethylene bags and sealed tightly to avoid external contamination and transported immediately to the laboratory. The soil samples were air-dried and kept at $70{ }^{\circ} \mathrm{C}$ for $30 \mathrm{~min}$ which stimulates the growth of actinomycetes by eliminating the vegetative Gram negative bacterial cells (Gebreyohannes et al. 2013, Janaki et al. 2014). 


\section{ISOLATION OF ACTINOMYCETES}

About $1 \mathrm{~g}$ of the pre-treated soil sample was serially diluted up to $10^{-6}$ dilution using conventional serial dilution technique. Aliquots containing $0.1 \mathrm{ml}$ of $10^{-3}, 10^{-4}$, $10^{-5}$ and $10^{-6}$ dilutions were spread and plated onto Actinomycetes Isolation Agar (AIA) (Sodium caseinate $2.0 \mathrm{gL}^{-1}$, L-Asparagine - $0.1 \mathrm{gL}^{-1}$, Sodium propionate - 4.0 $\mathrm{gL}^{-1}$, Dipotassium phosphate - $0.5 \mathrm{gL}^{-1}$, Magnesium sulphate - $0.1 \mathrm{gL}^{-1}$, Ferrous sulphate - $0.001 \mathrm{gL}^{-1}$, Agar - 15 $\mathrm{gL}^{-1}$, adjusted to a final $\mathrm{pH}$ of $8.1 \pm 0.2$ ) and Starch Casein Agar (SCA) (Starch - $10 \mathrm{gL}^{-1}$, Casein powder $1 \mathrm{gL}^{-1}$, Sea water $37 \mathrm{gL}^{-1}$, Agar - $15 \mathrm{~g} \mathrm{~L}^{-1}$ adjusted to a final $\mathrm{pH}$ of 7.2 \pm 0.2 ) (HiMedia Laboratories, Mumbai, India) ${ }^{1}$ for the isolation of actinomycetes (Roshan et al. 2013). The plates were incubated at $28{ }^{\circ} \mathrm{C}$ for $7-14$ days. The actinomycetes colonies were selected based on the morphology and further sub-cultured (Thirumurugan \& Vijayakumar 2013). The pure culture slants were maintained at $4{ }^{\circ} \mathrm{C}$ in AIA until further use.

\section{Test Pathogens}

The fish bacterial pathogens used in this study were Aeromonas caviae (MTCC 7725), A. hydrophila (MTCC 1739), Edwardsiella tarda (MTCC 2400) and Vibrio harveyi (MTCC 7954) which were obtained from Microbial Type Culture Collection and gene bank (MTCC), IMTECH, Chandigarh, India and $V$. anguillarum being a clinical isolate. The test pathogens Aeromonas caviae, Edwardsiella tarda and $A$. hydrophila were subcultured on nutrient agar medium (HiMedia, Mumbai, India) ${ }^{1}$ whereas, Vibrio harveyi and $V$. anguillarum were subcultured on nutrient agar supplemented with $2 \% \mathrm{NaCl}$ and incubated at $37^{\circ} \mathrm{C}$ for $24 \mathrm{~h}$. The test pathogens were stored in nutrient broth containing glycerol stock at $-20{ }^{\circ} \mathrm{C}$ until further use.

\section{SCREENing OF ANTIBACTERIAL ACTIVITy OF ACTINOMYCETES AGAINST TEST PATHOGENS}

\section{Primary screening}

The antibacterial activities of the isolated actinomycetes were examined by cross streak method (Ganesan et al. 2016). The Muller Hinton Agar (MHA) plates were prepared. For determining the activity against $V$. harveyi and $V$. anguillarum the MHA plates were supplemented with $2 \%$ of $\mathrm{NaCl}$. The actinomycetes were inoculated by a single streak in the center of the MHA plates and incubated at $28{ }^{\circ} \mathrm{C}$ for 7 days. The test organisms were streaked right angles to the original actinomycetes isolate and the plates were incubated at $37^{\circ} \mathrm{C}$ for $24 \mathrm{~h}$. Based on the zone of inhibition against the test pathogens, the potential actinomycetes were selected for secondary screening.

\section{SECONDARY SCREENING}

The isolates which showed promising activity in the primary screening were inoculated into ISP 1 broth (Hi Media, India) and incubated in a rotary shaker (120 rpm) at $28^{\circ} \mathrm{C}$ for 7 days. The turbidity of the test bacterial suspension was adjusted to $0.5 \mathrm{McF}$ arland standards in $0.85 \%$ saline. Lawn culture was spread using sterile swabs. Wells were bored using the wellbore on the MHA plates. The cell-free culture supernatant (CFS) $(100 \mu \mathrm{L})$ obtained from the actinomycetes isolates was used to screen antagonistic activity against test pathogens by the well diffusion method. The culture plates were incubated at $37{ }^{\circ} \mathrm{C}$ for $24 \mathrm{~h}$ and the zone of inhibition formed was measured in millimeters. All the experiments were repeated 3 times and the mean of the zone of inhibition was recorded. The actinomycetes isolate with potential antibacterial activity was selected for characterization and extraction of secondary metabolites.

\section{Characterization of THE POTENTIAL ISOlate}

\section{MoRPHOLOGICAL CHARACTERIZATION}

Actinomycetes with potential antibacterial activity against the selected fish and shellfish pathogens were identified up to the genus level on the basis of their aerial mass color, reverse side pigments, melanoid pigments and spore chain morphology based upon Bergey's Manual of Determinative Bacteriology (Williams et al. 1989, Sharma 2014). The arrangement of spores in the mycelium was observed under 1000x magnification by cover slip method and the slides were observed under the light microscope (Thenmozhi \& Kannabiran 2011). Gram's staining was also performed. The spore surface morphology was observed under scanning electron microscope.

${ }^{1}<$ http://www.himedialabs.com> 


\section{Culture characterization}

The potential isolates were grown in different media such as Actinomycetes Isolation Agar, Glucose soyabean meal agar, ISP 1(Tryptone Yeast Extract Broth), ISP 2 (Yeast Malt Agar), ISP3 (Oat Meal Agar), ISP 4 (Inorganic Salt Starch Agar), ISP 5 (Glycerol Asparagine Agar Base), ISP 6 (Peptone Yeast Extract Iron Agar), ISP 7 (Tyrosine Agar), Kuster's agar, Muller Hinton agar, nutrient agar, Starch Casein Agar and Sabouraud's Dextrose Agar for optimization of media for maximal growth and bioactivity (Gebreyohannes et al. 2013).

\section{Physiological Characterization}

The optimum $\mathrm{pH}$, temperature and sodium chloride tolerance of the potential isolate were studied. The $\mathrm{pH}$ of the ISP 1 broth was adjusted to 3, 5, 7, 9 and 11 . The flasks were inoculated with potential actinomycetes and incubated on a rotary shaker $(120 \mathrm{rpm})$ for 7 days at $28^{\circ} \mathrm{C}$. Four flasks $(250 \mathrm{~mL})$ containing ISP 1 broth were prepared and inoculated with actinomycetes and kept in the incubated rotary shaker $(120 \mathrm{rpm})$ at different temperatures ranging between $25-60{ }^{\circ} \mathrm{C}$ for a period of 7 days. The effect of sodium chloride on the growth of the isolate at various concentrations ranging between 0.5 $13 \%$ was also analyzed.

\section{UTILIZATION OF CARBON SOURCES}

The carbon utilization ability of the potential isolate was studied using carbon utilization agar (ISP 9) supplemented with $1 \%$ of various carbon sources like arabinose, cellobiose, glucose, inositol, raffinose and salicin (Nonomura 1974). Carbon utilization agar is used for the characterization of Streptomyces sp. on the basis of carbon source utilized by the Streptomyces isolate.

\section{BIOCHEMICAL CHARACTERIZATION}

Various biochemical tests were performed including indole, citrate utilization, methyl red, Voges Proskauer's, melanin production, oxidase, catalase, gelatinase, urease, amylase, lipase tests for the identification of potential isolate (Abirami et al. 2013).

\section{MOLECULAR TAXONOMIC CHARACTERIZATION}

The species level identification of the potential isolate was carried out by $16 \mathrm{~S}$ rRNA partial gene sequencing and construction of the phylogenetic tree. The genomic DNA of the isolate was extracted and 16S rRNA gene was amplified using a forward primer (27F5'AGAGTTTGATCMTGGCTCAG3') and a reverse primer (1492R-3'TACGGYTACCTTGTTACGACTT5'). Sequencing reactions were performed using ABI PRISM ${ }^{\circledR}$ BigDyeTM terminator cycle sequencing kits. The obtained 16S rDNA nucleotide sequence of isolate VITNK9 was searched through the NCBI GenBank data base for sequence similarity using the blast search tool. The program MUSCLE 3.7 was used for multiple sequence alignment (Edgar 2004). The program Gblocks $0.91 \mathrm{~b}$ was used to cure the resulting aligned sequences (Talavera \& Castresana 2007). The phylogeny analysis was performed using the program Mega- 6 software and the phylogenetic tree was constructed using the neighbor-joining method.

\section{SECONDARY STRUCTURE PREDICTION AND RESTRICTION SITE ANALYSIS OF 16S RRNA GENE}

The secondary structure of the isolate VITNK9 was predicted using the Genebee online software and restriction sites in the 16S rRNA of the potential isolate were analyzed by NEB cutter Version 2.0 available online.

\section{LARGE SCALE FERMENTATION}

The seed culture of the isolates which exhibited maximum activity in secondary screening was prepared by inoculating it into the ISP 1 broth, as the potential isolate grew excellently in ISP 1 medium (HiMedia, India) ${ }^{1}$ and then incubating it under shaking condition at $28^{\circ} \mathrm{C}$ for 3 days (Abirami et al. 2015). After incubation, about $10 \mathrm{~mL}$ of the cultures were transferred into $1 \mathrm{~L}$ of ISP 1 broth and incubated in an orbital shaker at $28^{\circ} \mathrm{C}$ for 7 days.

\section{Preparation of SOlvents extracts}

The fermented media was filtered using Whatman no.1 filter paper and the cell-free culture supernatant (CFS) was collected in a sterile conical flask. Liquid -liquid extraction technique was used to obtain the crude extract from the cell-free culture supernatant. Various solvents, ethyl acetate, chloroform and petroleum ether was used for the preparation of extracts and each extract was concentrated using a rotary evaporator.

\section{Antibacterial aCtivity}

The solvent extracts of the potential isolate VITNK9 were used to determine the antibacterial activity against the selected fish bacterial pathogens by the well diffusion method. The bacterial suspension of the test bacteria was adjusted to $10^{6} \mathrm{CFU} \mathrm{mL} \mathrm{m}^{-1}$ and a lawn culture was made on 
Muller-Hinton agar plates. The crude extract of the isolate was diluted to a concentration of $100 \mu \mathrm{g} / 100 \mu \mathrm{L}$ in dimethyl sulfoxide. Wells were bored using sterile wellbore on the agar plates and $100 \mu \mathrm{L}$ of the solvent extracts were added to each well. Ciprofloxacin was used as positive control and respective solvents were also used as negative control. The plates were incubated at $37^{\circ} \mathrm{C}$ for $18-24 \mathrm{~h}$. The zone of inhibition was measured in diameters to assess the antibacterial activity. All the experiments were performed in triplicates.

\section{DETERMINATION OF MINIMAL INHIBITORY CONCENTRATION (MIC)}

The MIC of the ethyl acetate extract of the active isolate was determined by serial dilution method in a sterilized 96 well plate. The sterile Muller-Hinton Broth $(100 \mu \mathrm{L})$ and $100 \mu \mathrm{L}$ of the overnight culture of the fish bacterial pathogens were added to each well. The ethyl acetate extract was serially diluted from $1 \mathrm{mg} \mathrm{mL}^{-1}$ to $0.01 \mathrm{mg} \mathrm{mL}^{-1}$ for determining the MIC of the active isolate. The MIC was considered as the lowest concentration of which showed no increase in the optimal density (OD 570) read at the microplate reader (Bio-Rad model 680 Microplate reader) ${ }^{2}$.

\section{GAS CHROMATOGRAPHY AND MASS SPECTROMETRY OF THE ETHYL ACETATE CRUDE EXTRACT}

The antibacterial bioactive compounds present in the ethyl acetate crude extract was identified by subjecting to the crude to GC-MS analysis using Perkin Elmer workstation Clarus $600 \mathrm{GC}$ coupled to a mass spectrometer Elite- 5MS $(30 \mathrm{~m} \times 0.25 \mathrm{~mm})$ width film depth of $250 \mu \mathrm{m}$ capillary tube was used. The instrument had an oven initial temperature of $55^{\circ} \mathrm{C}$ for $3 \mathrm{~min}$ and a ramp program which elevates from $6^{\circ} \mathrm{C} / \mathrm{min}$ up to $310^{\circ} \mathrm{C}$ further $3 \mathrm{~min}$ of the isothermal hold. Helium was used as a carrier gas with a flow rate split ratio of 10:1. About $2 \mu \mathrm{L}$ of sample was injected and the injector temperature maintained at $250{ }^{\circ} \mathrm{C}$. Total run time was $32 \mathrm{~min}$. The mass spectrum obtained was compared with spectra available in NIST-LIB 0.5 (National Institute of Standards and Technology) ${ }^{3}$ library for matching using the in-built software of GC-MS system (Wiley GC-MS2007). The concentration of individual compounds present was expressed as percentages through peak area presentation.

\footnotetext{
${ }^{2}$ Copyright (C) 2018 Bio-Rad Laboratories, Inc.

${ }^{3}<$ https://www.nist.gov/>
}

\section{Results}

\section{ISOLATION AND SCREENING OF ACTINOMYCETES}

Based on the colony morphology, a total of 72 actinomycetes were isolated from different terrestrial samples. Distinct actinomycetes colonies were observed in culture plates at $10^{-3}$ and $10^{-4}$ dilutions. Actinomycetes isolate exhibited different colony morphology and characteristics (size, shape, and colour) and the colonies were small to medium sized. The colour of the mature sporulating aerial mycelium ranged from white, gray, blue, light orange to violet. Brown, black and yellow coloured substrate mycelium was also recorded (Table 1). The isolate NN25 produced melanoid pigments. AIA or SCA agar media was used for isolation of all the 72 actinomycetes isolates. All the isolates were screened for antibacterial activity against the selected fish bacterial pathogens. About $18 \%$ of the isolates showed antibacterial activity in the primary cross streak method. Among them, only $7 \%$ of the isolates had abroad range of antibacterial activity against all the selected fish bacterial pathogens. The isolate VITNK9 exhibited abroad spectrum of activity against all the tested fish bacterial pathogens (Fig. 1). Those isolates with a broad range of antibacterial activity in primary screening were subjected to secondary screening by well diffusion method. Among all the isolates, the isolate VITNK9 showed a broad spectrum of activity against all the tested bacterial

Table 1. Cultural characteristics of potential actinomycetes isolates / Características de posibles aislamientos de actinomicetos en cultivo

\begin{tabular}{rcccc}
\hline S.No & $\begin{array}{c}\text { Actinobacterial } \\
\text { isolates code }\end{array}$ & $\begin{array}{c}\text { Media for } \\
\text { isolation }\end{array}$ & $\begin{array}{c}\text { Color of aerial } \\
\text { mycelium }\end{array}$ & $\begin{array}{c}\text { Reverse side } \\
\text { pigment }\end{array}$ \\
\hline 1 & NN1 & SCA & White & Purple \\
2 & KM1 & SCA & White & - \\
3 & MN2 & SCA & White & - \\
4 & BN2 & AIA & Greenish grey & Brown \\
5 & BN3 & SCA & White & - \\
6 & BN4 & AIA & Whitish grey & - \\
7 & NK5 & SCA & White & Pale yellow \\
8 & NK6 & AIA & Whitish grey & - \\
9 & NK7 & AIA & Grey & Black \\
10 & VITNK9 & AIA & Whitish grey & Pale yellow \\
11 & NK11 & SCA & Grey & Black \\
12 & NK24 & AIA & Whitish grey & - \\
13 & NN25 & AIA & White & Yellow \\
\hline
\end{tabular}


Figure 1. Primary screening of the isolate VITNK9 against the fish bacterial pathogens by cross streak method / Cribado primario del aislado VITNK9 contra los patógenos bacterianos de los peces por el método de raya cruzada
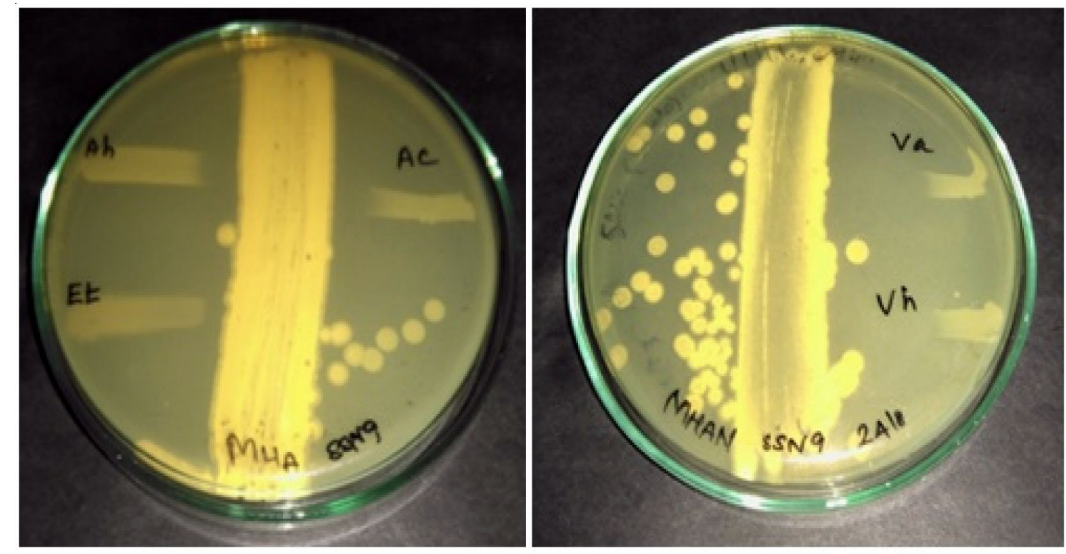

pathogens. The cell-free supernatant (CFS) of the isolate VITNK9 exhibited significant activity against Aeromonas caviae $(16 \mathrm{~mm})$, Aeromonas hydrophila $(16.5 \mathrm{~mm})$, Edwardsiella tarda $(17 \mathrm{~mm})$, Vibrio anguillarum $(15 \mathrm{~mm})$ and Vibrio harveyi $(14 \mathrm{~mm})$. The fish bacterial pathogen E. tarda was found to be more susceptible and V. harveyi was least susceptible for CFS treatment. The potential isolate was selected for further characterization.

\section{Morphological ChaRaCterization}

The colonies of the isolate VITNK9 were medium to large sized, powdery with irregular margin on AIA culture medium (Fig. 2a). The colour of the aerial mycelium was white to gray and substrate mycelium was pale yellow. The complete growth of the isolate was observed on the $14^{\text {th }}$ day. The isolate was Gram-positive and long chains of spores (oblong in shape) were observed under the light microscopic examination (1000X magnification). Smooth spore surface and hyphae with spiral spore chain morphology were observed under scanning electron microscope (Fig.2b). The isolate exhibited the typical structural features and morphology of Streptomyces sp. The morphological and biochemical characteristics of the isolate are given in Table 2 .

\section{BIOCHEMICAL CHARACTERIZATION}

The growth of the isolate VITNK9 on various media is given in Table 3. The isolate was characterized by the methods recommended by International Streptomyces Project. The isolate grew in abundance on ISP 3 and ISP 4 agar media. The isolate also grew excellent in AIA, ISP 1,
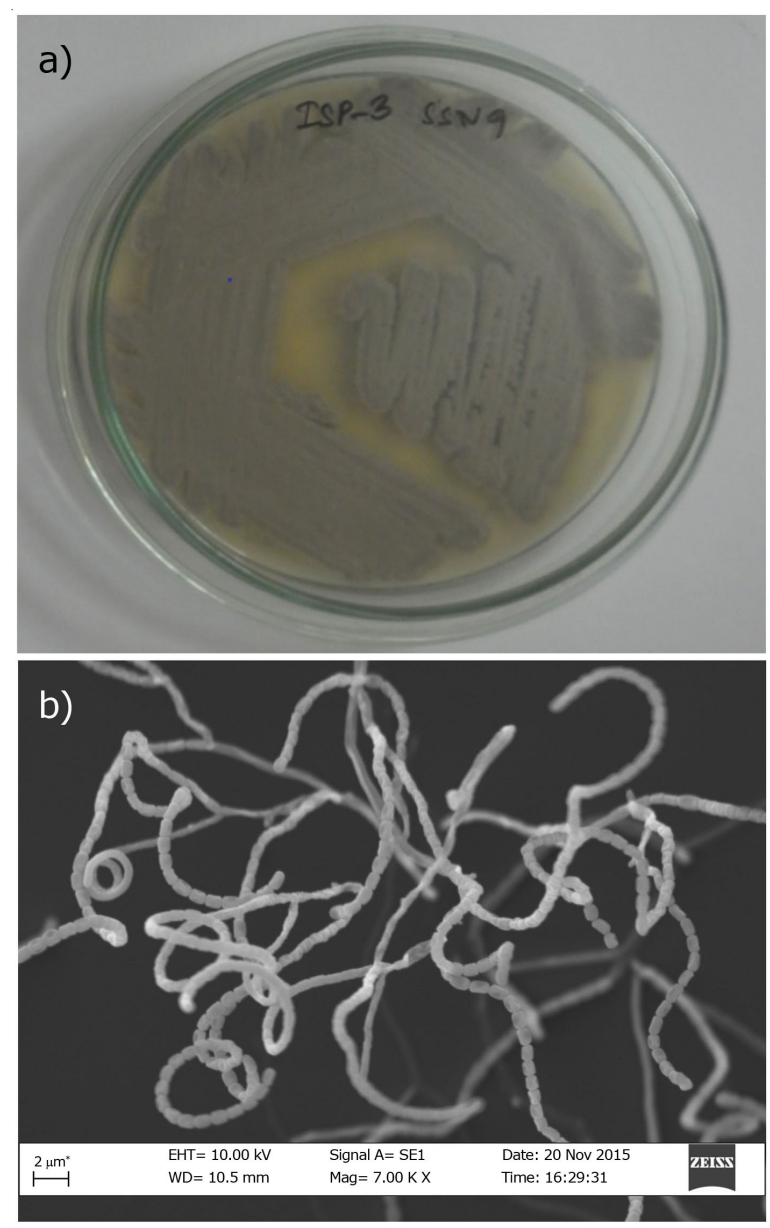

Figure 2. Streptomyces sp. VITNK9. a) Colony morphology and b) SEM spore morphology / Streptomyces sp. VITNK9. a) Morfología de las colonias y b) Morfología de las esporas de SEM 
Table 2. Characterization of the potential isolate Streptomyces sp. VITNK9 / Caracterización del aislamiento potencial Streptomyces sp. VITNK9

\begin{tabular}{|c|c|}
\hline Properties & \\
\hline Presence of aerial and substrate mycelium & + \\
\hline Sporophore morphology & Spiral \\
\hline Spore surface & Smooth \\
\hline Color of aerial mycelium & Grey \\
\hline Color of substrate mycelium & Light brown \\
\hline Shape of spores & Oblong \\
\hline Melanin pigment & - \\
\hline Indole production & - \\
\hline Methyl red test & + \\
\hline Vogesproskauer & - \\
\hline Citrate utilization & + \\
\hline Gelatin hydrolysis & - \\
\hline Catalase & + \\
\hline Oxidase & + \\
\hline Urease & + \\
\hline Starch hydrolysis & + \\
\hline $\mathrm{H}_{2} \mathrm{~S}$ production & - \\
\hline Nitrate reduction & _- \\
\hline TSI & $\mathrm{k} / \mathrm{k}$ \\
\hline \multicolumn{2}{|l|}{ Carbon source utilization } \\
\hline Arabinose & +++ \\
\hline Cellubiose & + \\
\hline Glucose & +++ \\
\hline Inositol & +++ \\
\hline Mannitol & +++ \\
\hline Raffinose & + \\
\hline Salicin & +++ \\
\hline
\end{tabular}

glucose soya meal broth, Kuster's agar and Nutrient agar. Good to moderate growth of the isolate was observed in SCA, ISP 5, ISP 6 and ISP 7. Poor growth was observed in ISP 2 and SDA media.

Different biochemical tests were carried out to identify the isolate. The isolate was found to be positive for methyl red test and citrate utilization test and negative for indole, Voges Proskauer's test and triple sugar iron test. It produced amylase, catalase, oxidase and urease, and was negative for nitrate reduction and gelatinase and lipase production. It utilized arabinose, glucose, inositol, mannitol, and salicin as carbon sources for maximal growth and cellubiose and raffinose were not used by the isolate. The culturing conditions were optimized with respect to culture media, $\mathrm{pH}$, temperature and $\mathrm{NaCl}$ concentration. The morphological and cultural characterization of the potential isolate revealed the nature and genera of the isolate.
Table 3. Characteristics of the isolate Streptomyces sp. VITNK9 on different media / Características del aislamiento de Streptomyces sp. VITNK9 en diferentes medios de cultivo

\begin{tabular}{|c|c|c|c|}
\hline Media & Growth & Aerial mycelium & $\begin{array}{l}\text { Substrate } \\
\text { mycelium }\end{array}$ \\
\hline ISP-1 & Excellent & Creamy white & - \\
\hline ISP-2 & Poor & Creamy white & White \\
\hline ISP-3 & Abundant & Powdery grey & Grey \\
\hline ISP-4 & Abundant & Grey & Grey \\
\hline ISP-5 & Moderate & Grey & Grey \\
\hline ISP-6 & Good & Grey & White \\
\hline ISP-7 & Good & Grey & White \\
\hline Nutrient Agar & Excellent & Whitish grey & White \\
\hline SDA & Poor & Pale white & Colourless \\
\hline SCA & Good & Powdery White & White \\
\hline AIA & Excellent & $\begin{array}{c}\text { White to grey } \\
\text { colonies }\end{array}$ & Pale white \\
\hline Kuster's agar & Excellent & Powdery white & Pale white \\
\hline Glucose soya meal broth & Excellent & Creamy white & - \\
\hline
\end{tabular}

\section{MOLECUlaR TAXONOMIC CHARACTERIZATION}

The blast search of the $16 \mathrm{~S}$ rDNA nucleotide sequence (876 bp) of the isolate with the NCBI, GenBank database revealed $83 \%$ similarity with Streptomyces vinaceusdrappus (KF554235). The 16S rDNA nucleotide sequence of the isolate was deposited in GenBank (NCBI) with an accession number (KX894540). Based on the molecular characterization and phylogeny of the isolate, it was confirmed to belong to the genus Streptomyces and designated as Streptomyces sp. VITNK9. The phylogenetic tree of the Streptomyces sp.VITNK9 is shown in the Figure 3.

\section{Secondary STRUCTURe PREDiCtion AND RESTRICTION SITE ANALYSIS OF 16S RRNA GENE}

The secondary structure for the isolate Streptomyces sp. VITNK9 was predicted by the greedy method. It was observed that the free energy of the thermodynamic structure was $-194.8 \mathrm{kcal} \mathrm{mol}^{-1}$, energy threshold was -4.0 with cluster factor 2 , conserved factor 2 , compensated factor 4, and conservativity 0.8 . The isolate had 59 restriction enzyme sites.

\section{ANTIBACTERIAL ACTIVITY OF THE SOLVENT EXTRACTS}

The isolate VITNK9 was extracted with different solvents including ethyl acetate, petroleum ether, and chloroform. The EA extract showed maximum antibacterial activity 


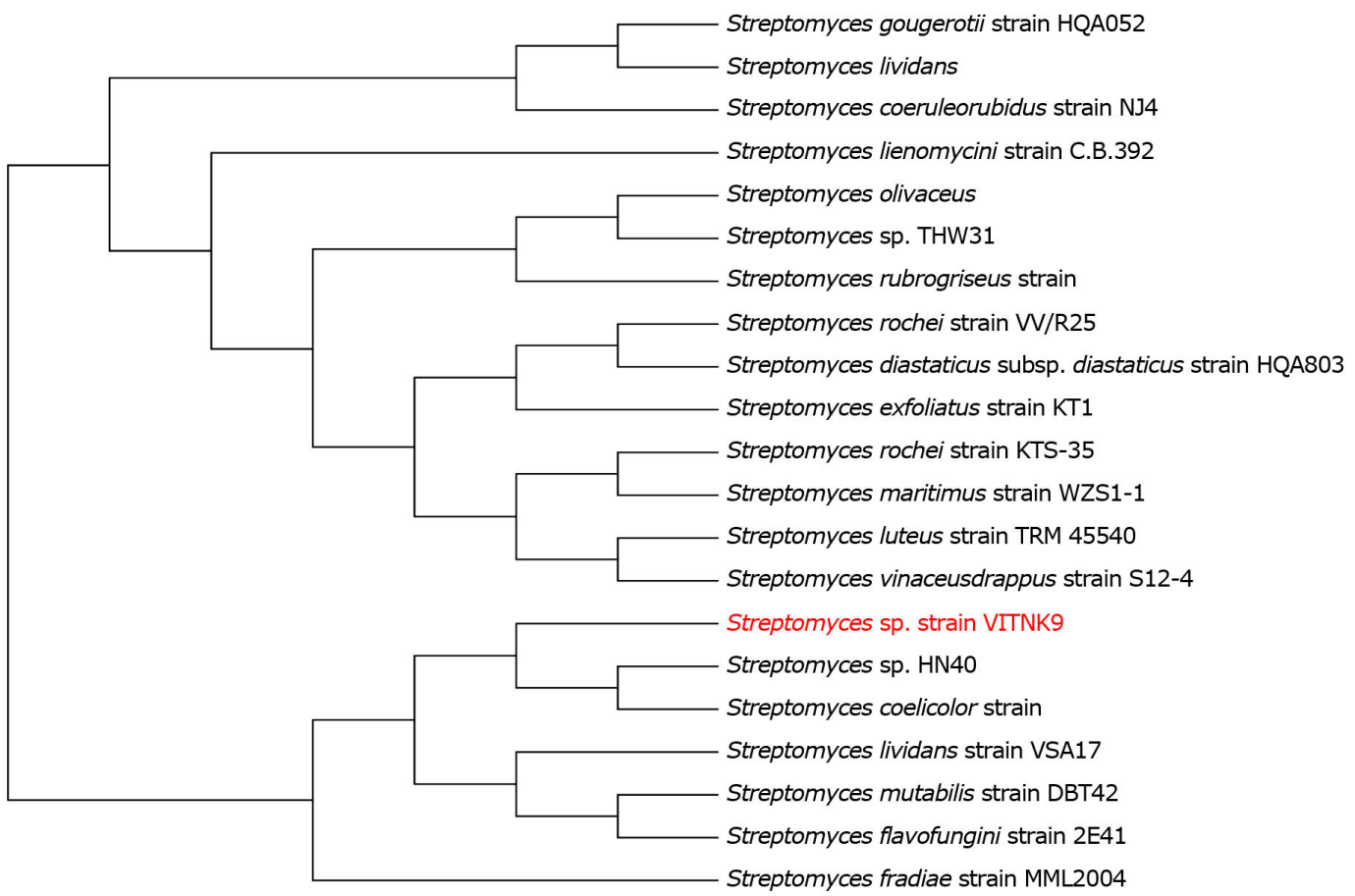

Figure 3. Phylogenetic analysis of Streptomyces sp. VITNK9 / Análisis filogenético de Streptomyces sp. VITNK9

when compared to other solvent extracts. The EA extract showed antibacterial activity against Aeromonas caviae $(15.33 \mathrm{~mm})$, Aeromonas hydrophila $(17.66 \mathrm{~mm})$, Edwardsiella tarda $(18.33 \mathrm{~mm})$, Vibrio anguillarum $(14.33$ $\mathrm{mm})$ and Vibrio harveyi $(14.33 \mathrm{~mm})$. The antibacterial activity observed with EA extract was comparatively higher than the activity observed with CFS (Table 4).

\section{DETERMINATION OF MINIMAL INHIBITORY CONCENTRATION (MIC)}

The MIC value of the ethyl acetate extract prepared from the active isolate was ranged between $0.03-0.125 \mathrm{mg} \mathrm{mL}^{-1}$. The MIC value of $A$. hydrophila and E. tarda was found to be $0.03 \mathrm{mg} \mathrm{mL}^{-1}$, for $V$. anguillarum and $V$. harveyi was $0.06 \mathrm{mg} \mathrm{mL}^{-1}$ and for $A$. caviae was $0.125 \mathrm{mg} \mathrm{mL}^{-1}$.

\section{Gas Chromatography and Mass Spectrometry of THE ETHYL ACETATE CRUDE EXTRACT}

The partial characterization of the EA crude extract of VITNK9 was carried out by GC-MS and the chromatogram obtained is shown in the Figure 4. The GC-MS spectrum of the EA crude extract revealed the presence of two major
Table 4. Antibacterial activity of the actinomycetes isolate VITNK9 against fish pathogens by well diffusion method / Actividad antibacteriana del aislamiento de actinomicetos VITNK9 frente a patógenos de peces por método de difusión de pozos

\begin{tabular}{lccc}
\hline \multirow{2}{*}{$\begin{array}{c}\text { Fish bacterial } \\
\text { pathogens }\end{array}$} & $\begin{array}{c}\text { VITNK9 } \\
\text { Cell free } \\
\text { supernatant }\end{array}$ & EA extract & $\begin{array}{c}\text { MIC of EA } \\
\text { extract } \\
\left(\mathrm{mg} \mathrm{mL}^{-1}\right)\end{array}$ \\
\cline { 2 - 4 } A. caviae & $14.57 \pm 0.48$ & $15.33 \pm 0.60$ & 0.13 \\
A. hydrophila & $16.28 \pm 1.37$ & $17.66 \pm 1.30$ & 0.03 \\
E. tarda & $17.00 \pm 1.29$ & $18.33 \pm 1.70$ & 0.03 \\
V. anguillarum & $14.71 \pm 0.68$ & $14.33 \pm 0.66$ & 0.06 \\
V. harveyi & $13.85 \pm 0.63$ & $14.33 \pm 0.88$ & 0.06 \\
\hline
\end{tabular}




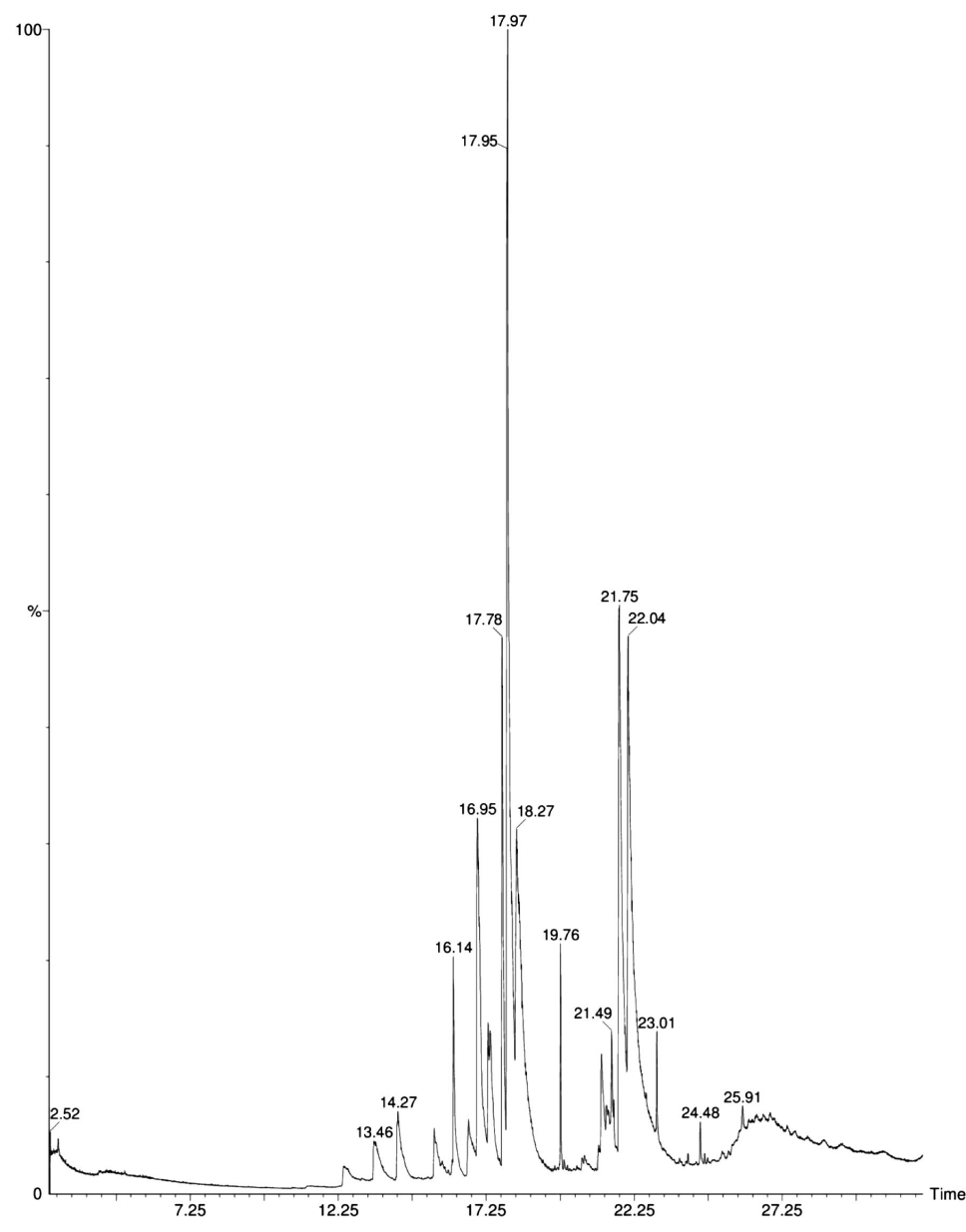

Figure 4. GC-MS chromatogram of VITNK9 ethyl acetate crude extract / Cromatograma GC-MS de extracto crudo de acetato de etilo de VITNK9

compounds (Table 5), pyrrolo[1,2-A] pyrazine-1,4-Dione hexahydro-3-(2-Methylpropyl) (56.67\%) and pyrrolo[1,2a]pyrazine-1,4-dione, hexahydro-3-(phenyl methyl)$(27.91 \%)$ respectively. The four peaks at the retention time 16.95, 17.95, 17.97 and 18.27 min represents isomers of pyrrolo[1,2-A] pyrazine-1,4-Dione hexahydro-3-(2Methylpropyl (NIST library matching). The peaks at the retention time 21.49 and $21.75 \mathrm{~min}$ represent the isomers of pyrrolo[1,2-a]pyrazine-1,4-dione, hexahydro-3-(phenyl methyl)-(NIST library matching).

\section{Discussion}

Actinomycetes are one of the most indispensable and vibrant bioactive compounds producing microorganisms found in both terrestrial and marine environments. These actinomycetes are fertile producers of antibiotics and new chemical entities as intracellular/ extra cellular secondary metabolites (Hassan et al. 2017). Soil samples have been screened for decades and only very few taxa of actinomycetes have been isolated and studied (AbdElnaby et al. 2016). The emerging bacterial diseases have hampered the growth of aquaculture tremendously. Hence, there is a need for developing antibacterial agents from natural sources to control and management of fish and shellfish bacterial diseases.

In the present study, 72 morphologically distinct actinomycetes were isolated from the terrestrial soil samples collected from Vellore, India. Among them, the potential isolate VITNK9 exhibited a significant antibacterial activity against fish and shellfish bacterial pathogens. Isolation of actinomycetes from the terrestrial environment has been inevitably reported earlier (Vaijayanthi et al. 2012, Cholarajan \& Vijayakumar 2013, Vijayakumar \& Malathi 2014). The isolate VITNK9 produced whitish gray aerial mycelium and pale yellow substrate mycelium. It also had an earthy odour which is the known characteristics of the Streptomyces sp. The colonies of actinomycetes with white and greyish aerial 
Table 5. GC-MS analysis of the ethyl acetate extract of VITNK9 / Análisis GC-MS del extracto de acetato de etilo de VITNK9

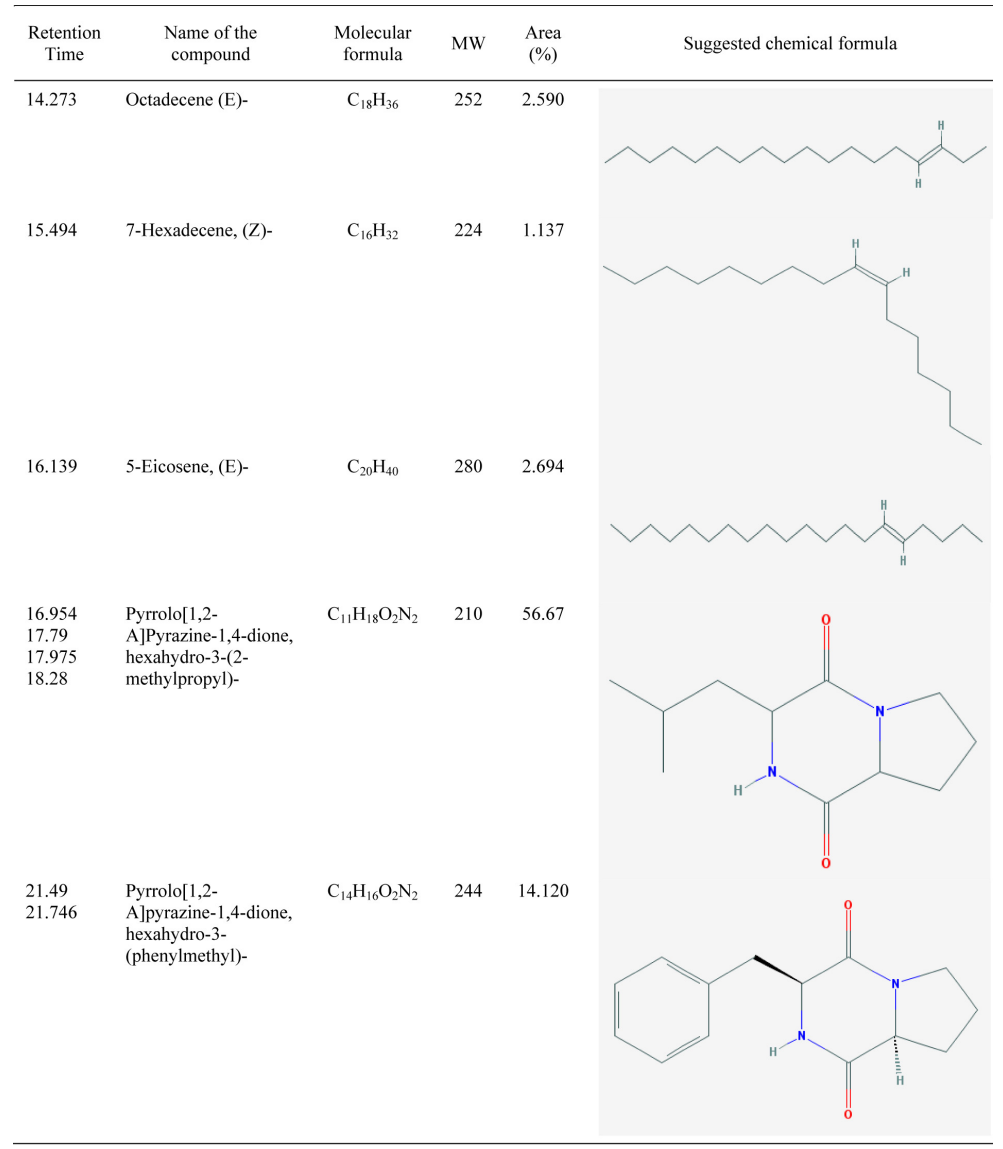

mycelium and yellow substrate mycelium have been reported earlier (Gebreyohannes et al. 2013). The isolate also grew excellently well on ISP3, ISP4, nutrient agar, Kuster's agar and AIA. The potential actinomycetes isolate VITNK9 was characterized by morphological, biochemical, physiological and molecular characterization. The isolate was identified based on the comparison with the keys for classification and identification by Nonomura and Bergey's manual of Determinative Bacteriology (Nonomura 1974, Williams et al. 1989). The 16S rRNA gene sequencing remains as a significant and reliable tool for the identification and confirmation of the actinomycetes up to the genus and species levels. The isolate was identified as Streptomyces sp. and designated as Streptomyces sp. VITNK9 on the basis of the molecular taxonomic characterization (Thirumurugan \& Vijayakumar 2015, Augustine et al. 2016, Jenifer et al. 2018).

In the present study, $18 \%$ of the isolates showed antibacterial activity against the fish and shellfish bacterial pathogens. There are many reports which illustrate the antimicrobial activity of the actinomycetes isolated from different habitats (Cho et al. 2012, Chaudhary et al. 2013, Gebreyohannes et al. 2013, Ganesan et al. 2017). Antibacterial activity of actinomycetes against human as well as fish bacterial pathogens has been reported (Babuselvam et al. 2016, Jenifer et al. 2018). Mohan et al.(2016) have reported on the antimicrobial activity of actinomycetes extracts against the fish bacterial pathogens. Antibacterial activity of actinobacterial isolates against $A$. hydrophila, A. sorbia and E. tarda has already been reported (Patil et al. 2001).

In our study, among the various solvents used the ethyl acetate crude extract of the potential Streptomyces sp. VITNK9 had a broad spectrum antibacterial activity against the tested fish and shell fish bacterial pathogens. In a study, the protein extracted from Streptomyces spp. KV3 showed an inhibitory activity against Vibrio harveyi $(17 \mathrm{~mm})$ Aeromonas hydrophila $(10 \mathrm{~mm})$ and Vibrio alginaticus $(9 \mathrm{~mm}$ ) (Rani \& Doss 2016). Similar findings were reported where the ethyl acetate extract of 
actinomycetes showed antibacterial activity against fish bacterial pathogens (Patil et al. 2016a,b). The ethyl acetate crude extract of the potential isolate VITNK9 showed a broad range of antibacterial activity with the MIC value ranging between $0.03-0.125 \mathrm{mg} \mathrm{mL}^{-1}$ against the fish and shellfish pathogens A. caviae, A. hydrophila, E. tarda, $V$. harveyi and $V$. anguillarum. The effectiveness of the antibacterial compounds does vary from one species to other, depending upon the factors like sampling site, media composition to the genetic potential of an organism. Tuan et al. (2017) have also reported the antibacterial activity shown by the endophytic actinomycetes (MTR 711, MTR 622 and MTL 121) with the MIC of 93.30 to 300 $\mathrm{mg} \mathrm{mL}-1$ against $A$. hydrophila, $A$. caviae and $S$. agalactiae. It was also reported that the partially purified bioactive compound (protein) showed moderate antibacterial activities against the fish bacterial pathogens A. hydrophila, $V$. harveyi and $V$. alginolyticus (PushpaRani \& Doss 2016).

The EA crude extract was subjected to GC-MS analysis to obtain a rudimentary idea of the secondary metabolites present in the extract. The GC-MS analysis revealed the presence of pyrrolo[1,2-A] pyrazine-1,4-dione, hexahydro3-(2-Methylpropyl) in the EA crude extract which could be responsible for inhibiting fish bacterial pathogens. Antioxidant (free radical scavenging) activity of pyrrolo [1,2-A] pyrazine-1,4-dione has recently been reported (Ser et al. 2015). A report illustrates that Streptomyces sp. could produce actinonin with anti-VaPDF activity which provides resistance against $V$. anguillarum (Yang \& Sun 2016). Antibacterial activity of EA extract containing Pyrrolo[1,2-a] pyrazine-1,4-dione, hexahydro- 3-(2methylpropyl) extracted from Streptomyces sp. VITMK1 was recently reported from the authors lab (Manimaran et al. 2017). In the present study the peak area of pyrrolo [1,2-A] pyrazine-1,4-dione, hexahydro-3-(2-Methylpropyl) was found to be $56.67 \%$. The pyrrolo compound was predicted and the structure was obtained with a molecular formula of $\mathrm{C}_{11} \mathrm{H}_{18} \mathrm{O}_{2} \mathrm{~N}_{2}$ and a molecular weight of $210 \mathrm{kDa}$.

Streptomyces sp. VITNK9 isolated from the terrestrial soil sample found to be a rich source of antibacterial compounds against the fish and shellfish pathogens. The secondary metabolites (Pyrrolo [1,2-A] pyrazine-1,4-dione and hexahydro-3-(2-Methylpropyl) present in the ethyl acetate crude extract needs to be explored further to develop as an antibacterial agent against fish and shellfish pathogens.

\section{ACKNOWLEDGEMENTS}

The authors sincerely thank the management of Vellore Institute of Technology for providing necessary facilities to carry out this research work.

\section{LITERATURE CITED}

Abd-Elnaby H, GAbo-Elala, U Abdel-Raouf, AAbd-Elwahab \& M Hamed. 2016. Antibacterial and anticancer activity of marine Streptomyces parvus: Optimization and application. Biotechnology and Biotechnological Equipment 30: 180-191.

Abirami M, VG Khanna \& K Kannabiran. 2013. Antibacterial activity of marine Streptomyces sp. isolated from Andaman \& Nicobar Islands, India. International Journal of Pharma and Bio Sciences 4: 280-286.

Abirami M, JV Gopal \& K Kannabiran. 2015. Extraction and identification of antibacterial compound from marine Streptomyces sp. VITAK1 isolated from the coast of Andaman and Nicobar Islands, India. Applied Biochemistry and Microbiology 51: 406-410.

Aly SM \& A Albutti. 2014. Antimicrobials use in aquaculture and their public health impact. Journal of Aquaculture Research and Development 5: 247.

Augustine D, JC Jacob \& R Philip. 2016. Exclusion of Vibrio spp. by an antagonistic marine actinomycete Streptomyces rubrolavendulae M56. Aquaculture Research 47: 29512960.

Babuselvam M, A Panneerselvam, K Kanimozhi \& G Kavitha. 2016. Antibacterial potential of actinomycetes from Seagrass against human and aquaculture pathogens. Journal of Microbiology and Biotechnology Research 6: 32-38.

Berdy J. 2005. Bioactive microbial metabolites. Journal of Antibiotics 58: 1-26.

Chaudhary HS, J Yadav, AR Shrivastava, S Singh, AK Singh \& N Gopalan. 2013. Antibacterial activity of actinomycetes isolated from different soil samples of Sheopur (A city of central India). Journal of Advanced Pharmaceutical Technology \& Research 4: 118-123.

Cho SS, YH Choi, JR Simkhada, P Mander, DJ Park \& JC Yoo. 2012. A newly isolated Streptomyces sp. CS392 producing three antimicrobial compounds. Bioprocess and Biosystems Engineering 35: 247-254.

Cholarajan A \& R Vijayakumar. 2013. Isolation, identification, characterization, and screening of antibiotic producing actino-bacteria from the crop field of Thanjavur district, Tamilnadu, India. International Journal of Science and Research 4: 55-60.

Edgar R. 2004. MUSCLE: Multiple sequence alignment with high accuracy and high throughput. Nucleic Acids Research 32: 1792-1797. 
Ganesan P, AD Reegan, RHA David, MR Gandhi, MG Paulraj, NA Al-Dhabi \& S Ignacimuthu. 2016. Antimicrobial activity of some actinomycetes from Western Ghats of Tamil Nadu, India. Alexandria Journal of Medicine 53: 101-110.

Gebreyohannes G, M Feleke, S Sahile \& N Raja. 2013. Isolation and characterization of potential antibiotic producing actinomycetes from water and sediments of Lake Tana, Ethiopia.Asian Pacific Journal of Tropical Biomedicine 3(6): 426-435.

Goarant C, F Merien, F Berthe, I Mermoud \& P Perolat. 1999. Arbitrarily primed PCR to type Vibrio spp. pathogenic for shrimp. Applied and Environmental Microbiology 65: 1145-1151.

Hassan SS, K Anjuma, SQ Abbas, A Akhter, BI Shaguftac, SAA Shaha \& U Tasneem. 2017. Emerging biopharmaceuticals from marine actinobacteria. Environmental Toxicology and Pharmacology 49: 34-47.

Janaki T, BK Nayak \& T Ganesan. 2014. Different pretreatment methods in selective isolation of actinomycetes from mangrove sediments of Ariyankuppam back water estuary, Puducherry. International Journal of Advanced Research in Biological Sciences 1: 154-163.

Jenifer JA, R Remya, S Velmurugan, M Michaelbabu \& T Citarasu. 2018. Streptomyces castaneoglobisporus AJ9, A haloalkaliphilic actinomycetes isolated from solar salt works in southern India and its pharmacological properties. Indian Journal of Geo-Marine Sciences 47: 475-488.

Lazzarini A, G Cavaletti \& F Marinelli. 2000. Rare genera of actinomycetes as potential producers of new antibiotics. Antonie Van Leeuwenhoek 78: 399-405.

Letchumanan V, K Chan \& L Le. 2014. Vibrio parahaemolyticus: A review on the pathogenesis, prevalence, and advance molecular identification techniques. Frontiers in Microbiology 5: 705.<doi:10.3389/ fmicb.2014.00705>

Manimaran M, JV Gopal \& K Kannabiran. 2017. Antibacterial activity of Streptomyces sp. VITMK1 isolated from mangrove soil of Pichavaram, Tamil Nadu, India. Proceedings of the National Academy of Sciences India, Section B 87(2): 499-506.

Mohan G, AK Thangappanpillai \& B Ramasamy. 2016. Antimicrobial activities of secondary metabolites and phylogenetic study of sponge endosymbiotic bacteria, Bacillus sp. at Agatti Island, Lakshadweep Archipelago. Biotechnology Reports 11: 44-52.

Nonomura H. 1974. Key for classification and identification of 458 species of the Streptomycetes included in ISP. Journal of Fermentation Technology 52: 78-92.

Patil R, G Jeyasekaran \& SA Shanmugam. 2001. Control of bacterial pathogens, associated with fish diseases, by antagonistic marine actinomycetes isolated from marine sediments. Indian Journal of Marine Sciences 30: 264-267.
Patil R, G Jeyasekaran \& SA Shanmugam. 2016a. Incidence and activity of actinomycetes isolated from marine samples from Thoothukkudi, Tamil Nadu, on the east coast of India, against bacterial pathogens of fish. International Journal of Science and Nature 7: 541-549.

Patil R, G Jeyasekaran \& SA Shanmugam. 2016b. Occurrence and antibacterial activity of actinomycetes isolated from marine samples from Thoothukkudi, Tamil $\mathrm{Nadu}$, on the east coast of India, against fish pathogens. International Journal of Science and Nature 6: 338-347.

Pushpa-Rani KT \& A Doss. 2016. Purification and antibacterial activity of marine actinomycetes against human and fish pathogens. Journal of Marine Science: Research and Develpoment 6: 4-7.

Roshan K, A Tarafdar, K Saurav, S Ali, SA Lone, S Pattnaik, A Tyagi, K Biswas \& ZA Mir. 2013. Isolation and screening of bioactive compound from actinomycetes isolated from salt pan of Marakanam district of the state Tamil Nadu, India. Elixir International Journal 61: 16826-16831.

Santhakumari S, A Kannappan, SK Pandian, N Thajuddin, RB Rajendran \& AV Ravi. 2016. Inhibitory effect of marine cyanobacterial extract on biofilm formation and virulence factor production of bacterial pathogens causing vibriosis in aquaculture. Journal of Applied Phycology 28: 313-324.

Selvakumar D, K Arun, S Suguna, D Kumar \& K Dhevendaran. 2010. Bioactive potential of Streptomyces against fish and shellfish pathogens. Iranian Journal of Microbiology 2: 156-163.

Ser HL, UD Palanisamy, WF Yin, SNA Malek, KG Chan, BH Goh \& LH Lee. 2015. Presence of antioxidative agent, Pyrrolo [1, 2-a] pyrazine-1, 4-dione, hexahydro-in newly isolated Streptomyces mangrovisoli sp. nov. Frontiers in Microbiology 6: 854. <doi: 10.3389/fmicb.2015.00854>

Sharma M. 2014. Actinomycetes: Source, identification, and their applications. International Journal of Current Microbiology and Applied Sciences 3: 801-832.

Sihag RC \& P Sharma. 2012. Probiotics: The ecofriendly measure for sustainable development in aquaculture. Journal of Fisheries and Aquatic Sciences 7(2): 72-103.

Talavera G \& J Castresana. 2007. Improvement of phylogenies after removing divergent and ambiguously aligned blocks from protein sequence alignments. Systematic Biology 56: 564-577.

Thenmozhi M \& K Kannabiran. 2011. Anti-Aspergillus activity of Streptomyces sp.VITSTK7 isolated from Bay of Bengal coast of Puducherry, India. Journal of Natural \& Environmental Sciences 2: 1-8.

Thirumurugan D \& R Vijayakumar. 2013. Exploitation of antibacterial compound producing marine actinobacteria against fish pathogens isolated from less explored environments. Asian Journal of Pharmaceutical Research 3: 75-78. 
Thirumurugan D \& R Vijayakumar. 2015. Characterization and structure elucidation of antibacterial compound of Streptomyces sp. ECR77 Isolated from East Coast of India. Current Microbiology 70: 745-755.

Tuan NN, TT Trang, S Yaemkong, P Jaipong \& P Kotham. 2017. Isolation and evaluation of antimicrobial activity of endophytic actinobacteria on May Chang tree (Litsea cubeba) against pathogenic bacteria causing diseases on common carp and tilapia. SNRU Journal of Science and Technology 9: 560-567.

Vaid N \& ST Sajeevan. 2016. Screening marine bacterium strains of Actinomycetes as antagonists to pathogenic Vibrios, molecular identification of potent strain and media optimization by: Plackett-Burman analysis and response surface methodology. Invertis Journal of Science \& Technology 9: 79-93.

Vaijayanthi, G, A Cholarajan \& R Vijayakumar. 2012. Isolation, characterization and antibacterial activity of terrestrial actinobacteria in the soils of Thanjavur District, Tamil Nadu. Indian Journal of Science and Technology 4: 132-139.

Vijayakumar R \& R Malathi. 2014. Isolation, characterization and antibacterial activity of actinobacteria from dye polluted soils of Tirupur. Facta Universitatis, Series: Medicine and Biology 16: 43-48.
Wang L, Y Chen, H Huan, Z Huang, H Chen \& Z Shao. 2015. Isolation and identification of Vibrio campbellii as a bacterial pathogen for luminous vibriosis of Litopenaeus vannamei. Aquaculture Research 46: 395-404.

Williams ST, M Goodfellow \& G Alderson. 1989. Genus Streptomyces. In: Williams ST, ME Sharpe \& JG Holt (eds). Bergey's Manual of Systematic Bacteriology 4: 24522492.Williams \& Wilkins, Baltimore.

Yang N \& C Sun. 2016. The inhibition and resistance mechanisms of actinonin, isolated from marine Streptomyces sp. NHF165, against Vibrio anguillarum. Frontiers in Microbiology 7: 1-11. <doi: 10.3389/fmicb.2016.01467>

You JL, LX Cao, GF Liu, SN Zhou, HM Tan \& YC Lin. 2005. Isolation and characterization of actinomycetes antagonistic to pathogenic Vibrio spp. from nearshore marine sediments. World Journal of Microbiology and Biotechnology 21: 679-682.

Zheng ZH, W Zeng, YJ Yang, ZY Huang, J Li, HR Cai \& WJ Su. 2000. Detection of antitumor and antimicrobial activities in marine organism associated Actinomycetes isolated from the Taiwan Straint, China. FEMS Microbiology Letters 188: 87-91.

Received 18 August 2017 and accepted 13 June 2018

Editor: Claudia Bustos D. 